\title{
Analisa Performansi Algoritma Penjadwalan Proportional Fairness Dan Log Rule Dengan Skenario Multicell Pada Sistem 3GPP LTE
}

\author{
Muhammad Dimas Arfianto ${ }^{1}$, Ridha Muldina Negara ${ }^{2}$, Indrarini Dyah Irawati ${ }^{3}$ \\ ${ }^{1,2}$ Program Studi S1 Teknik Telekomunikasi, Fakultas Teknik Elektro, Universitas Telkom \\ ${ }^{3}$ Program Studi D3 Teknik Telekomunikasi, Fakultas Ilmu Terapan, Universitas Telkom \\ J1. Telekomunikasi Terusan Buah Batu Bandung 40257 Indonesia \\ Email korespondensi : arfiadimas@gmail.com
}

Dikirim 23 Maret 2016, Diperbaiki 16 April 2016, Diterima 21 April 2016

\begin{abstract}
Abstrak - Teknologi Long Term Evolution (LTE) dikembangkan dengan tujuan untuk mengurangi biaya yang dikeluarkan oleh pengguna maupun operator jasa telekomunikasi, memperluas daerah jangkauan, menambah kapasitas sistem, dan mengurangi delay. Dengan spesifikasi yang tinggi, LTE diharapkan mampu memberikan kemudahan pelanggan dalam mengakses layanan Voice over IP, Streaming, dan Video Conference. LTE diharapkan mampu memberikan layanan dengan besar throughput yang tinggi dan delay yang rendah. Padahal tidak semua user membutuhkan throughput yang sama besar namun yang dibutuhkan adalah kesesuaian pengendalian delay dan fairness index untuk setiap user dengan tetap memperhatikan batasan throughput. Untuk mendapatkan kinerja dan hasil yang maksimal tersebut pada LTE diperlukan sistem algoritma penjadwalan yang baik. Pada penelitian ini, dianalisis performansi LTE dengan parameter Delay, Packet loss, Throughput, dan Fairness Index menggunakan algoritma penjadwalan Proportional Fairness dan Log Rule pada LTE-Simulator dengan skenario menggunakan trafik VoIP, Video dan Best Effort. Hasil penelitian ini menunjukan bahwa penjadwalan algoritma Proportional Fairness lebih baik dalam menangani layanan VoIP, sedangkan algoritma Log Rule lebih baik dalam menangani layanan Video. Hal ini menandakan kedua algoritma ini sangat cocok digunakan untuk jaringan LTE dengan kondisi trafik layanan real-time, tetapi tidak untuk layanan non real-time seperti layanan Best Effort.
\end{abstract}

Kata kunci - LTE, Algoritma Penjadwalan, Proportional Fairness, Log Rule

\begin{abstract}
Long Term Evolution technology (LTE) was developed in order to reduce the costs incurred by the users and telecommunication operators, extend the coverage area, increase system capacity, and reduce the delay. With a high specification, LTE is expected to provide convenience for customers to access the services of Voice over IP, Streaming, and Video Conference. LTE also expected to provide great service with a high throughput and low delay. Though not all users require the same throughput, but what is needed is control the delay and fairness index for each user with regard to the throughput limitations. To get the maximum performance and results on LTE, it takes good scheduling algorithm system. In this study, analyze the performance of LTE with Delay parameter, Packet loss, Throughput and Fairness Index using Proportional Fairness scheduling algorithm and Log Rule on LTE-Simulator using VoIP traffic, Video, and Best Effort. Also in this study indicates that the Proportional Fairness scheduling algorithms better at managing VoIP service, whereas Log Rule Algorithm better at managing video services. This indicates that both algorithms are well suited for LTE networks with traffic conditions of real-time services, but not for non real-time services such as Best Effort.
\end{abstract}

Keywords - LTE, Scheduling Algorithm, Proportional Fairness, Log Rule.

\section{PENDAHULUAN}

Beragamnya perkembangan layanan telekomunikasi saat ini menjadi satu alasan dikembangkannya teknologi Long Term Evolution (LTE) oleh badan 3rd Generation Partnership Project (3GPP) [8]. Teknologi ini juga merupakan evolusi teknologi GSM/EDGE dan UMTS/HsxPA yang dikembangkan oleh badan $3 G P P$. Dengan spesifikasi yang tinggi, teknologi Long Term Evolution (LTE) diharapkan mampu memberikan kemudahan pelanggan dalam mengakses layanan Voice over IP, Streaming, dan Video Conference. LTE diharapkan mampu memberikan layanan dengan throughput yang tinggi dan delay yang rendah. 
Pada penelitian sebelumnya yang dilakukan oleh Karimah Amatullah, Sitti, dengan judul Analisis Perbandingan Algoritma Penjadwalan PF dan MLWDF pada Kasus Multicell Jaringan Long Term Evolution, 2012, dilakukan percobaan dengan menggunakan algoritma penjadwalan yang hanya mempertimbangkan faktor throughput untuk user tanpa memperhatikan delay dan jenis trafik yang dilewatkan. Padahal, tidak semua user membutuhkan throughput yang sama besar, namun kesesuaian pengendalian delay dan fairness index untuk setiap user dengan tetap memperhatikan batasan throughput [11]. Dengan adanya algoritma penjadwalan yang baik, diharapkan QoS dapat terjaga.

Oleh karena itu dalam penelitian ini, dilakukan analisis terhadap performansi penjadwalan algoritma Proportional Fairness dan Log Rule dengan menguji coba di dua skenario yaitu perubahan jumlah user 25 , 50, 75, 100 dan kecepatan user 3, 30, $120 \mathrm{~km} / \mathrm{jam}$. Performansi kedua algoritma tersebut dianalisis menggunakan simulator LTE-Sim dengan menghitung parameter QoS yaitu Delay, Packet Loss Ratio, Throughput, dan Fairness Index. LTE-Sim disediakan gratis dengan lisensi dibawah GPLv3 [4].

\section{METODOLOGI PENELITIAN}

LTE adalah suatu teknologi seluler dengan arsitektur berbasis IP yang distandarisasi oleh $3^{\text {rd }}$ Generation Partnership Project (3GPP).

\begin{tabular}{cccc}
\multicolumn{4}{c}{ Tabel 1. Karakteristik LTE [7] } \\
\hline Cell Radius & $\begin{array}{c}\text { Up to } 5 \mathrm{~km} \\
\text { QPSK, } 16\end{array}$ & Mobility & UP to $350 \mathrm{~km} / \mathrm{h}$ \\
Modulation & $\begin{array}{c}\text { QAM, } \\
\text { 64QAM }\end{array}$ & Duplexing & FDD, TDD \\
$\begin{array}{c}\text { Downlink } \\
\text { peak data } \\
\text { rate }\end{array}$ & $100 \mathrm{Mbps}$ & $\begin{array}{c}\text { Multiple } \\
\text { Access }\end{array}$ & $\begin{array}{c}\text { OFDMA } \\
\text { (Downlink) }\end{array}$ \\
$\begin{array}{c}\text { Uplink peak } \\
\text { data rate } \\
\text { Antenna }\end{array}$ & Mo Mbps & $\begin{array}{c}\text { Multiple } \\
\text { Access }\end{array}$ & $\begin{array}{c}\text { SC FDMA } \\
\text { (Uplink) }\end{array}$ \\
$\begin{array}{c}\text { Scheduling } \\
\text { Algorithm }\end{array}$ & \multicolumn{3}{c}{ Proportional Fairness dan Log Rule } \\
\hline
\end{tabular}

\section{A. Penjadwalan Arah Downlink LTE [3]}

Packet scheduler harus didesain reaktif terhadap perubahan pada channel dan jenis trafik, agar dapat merespon dengan cepat persyaratan QoS dari suatu layanan. Karena suatu paket pada suatu flow memiliki persyaratan QoS nya masing-masing. Scheduler harus cerdas dalam memutuskan urutan pertransmisian paket. Paket memiliki urutan prioritas tergantung dari persyaratan QoS layanan paket tersebut.

Pengambilan keputusan urutan didasari dari berbagai metrik yang dilaporkan dari layer lain dalam protocol slack. Metrik-metrik yang biasa digunakan adalah.
1. Nilai CQI yang dilaporkan oleh user.

2. Metrik QoS seperti batasan delay atau throughput minimum.

3. Jumlah transmisi yang sudah dilaksanakan.

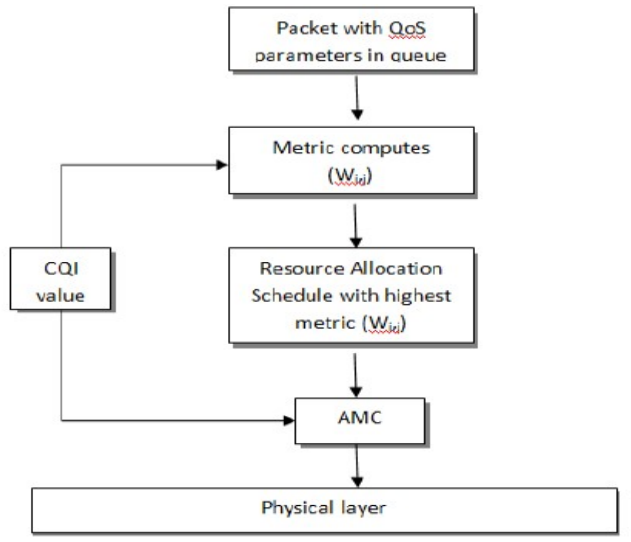

Gambar 1. Prosedur Penjadwalan Paket Arah Downlink [3]

Berikut ini prosedur dari penjadwalan paket arah downlink, dijabarkan sebagai berikut.

1. eNB membuat suatu daftar yang berisi paket siap untuk dikirimkan. Setiap paket yang berada pada daftar tersebut telah ditambahkan informasi mengenai CQI feedback dan MAC queue length.

2. Dilakukan penghitungan metrik wi,j sesuai dengan karakteristik dari tiap algoritma penjadwalan.

3. eNB menempatkan tiap sub-channel kedalam paket yang memiliki nilai metrik tertinggi.

4. Untuk tiap paket yang dijadwalkan, eNB menghitung ukuran dari transport block, yaitu jumlah data yang akan dikirimkan pada lapis MAC pada tiap TTI. Dalam hal ini, eNB menggunakan AMC untuk memetakan nilai CQI feedback dengan memilih skema coding dan modulasi (MCS) yang tepat sehingga eNB memperoleh ukuran transport block (TB) yang tepat dari skema coding dan modulasi yang dipilih tersebut.

5. Pada akhir prosedur penjadwalan, eNB menambahkan bearer ke tiap paket yang akan dijadwalkan, yang digunakan untuk mengatur transmisi paket pada lapis MAC.

\section{B. Proportional Fairness [7]}

Algoritma penjadwalan ini menetapkan sumber daya ratio berdasarkan kualitas kanal dan throughput user sebelumnya. Tujuan dari penggunaan algoritma Propotional Fairness ini adalah untuk memaksimalkan throughput total jaringan dan untuk menjamin fairness antar flow. Pada Propotional Fairness metrik wi,j didefinisikan sebagai rasio dari data rate pada saat itu (ri,j) dan rata-rata data rate sebelumnya, yaitu: 


$$
W i j \quad \frac{r i, j}{R i}
$$

Dimana ri,j dihitung oleh modul AMC berdasarkan nilai CQI dari UE yang bersangkutan. Sedangkan (Ri) merupakan data rate rata-rata.

\section{Log Rule [9]}

Log Rule adalah algoritma penjadwalan yang mampu meminimalkan rata - rata delay dan mampu meminimalkan probabilitas dari jumlah antrian atau seluruh antrian sepanjang buffer yang ada. Ketika antrian user bertambah, Log Rule mengalokasikan tiap paket dengan cara memperhatikan keseimbangan dari seluruh delay antrian yang bertujuan untuk memaksimalkan throughput. Algoritma ini juga dikenal dengan algoritma delay - optimal.

Untuk paket real time, algoritma penjadwalan ini menghitung nilai matrik yang dimaksud dengan formula persamaan.

$$
w i, j=b i \log (c+a i W i(t)) \times R j(t)
$$

Untuk paket non-real time, nilai $(c+a i W i(t))$ diabaikan, karena paket non-real time tidak mengharuskan adanya delay parameter bi = $1 \sqrt[1]{R i}, c=1.1$, dan $a i=\frac{5}{d i}$, di adalah waktu delay maksimum paket pada user ke-i. Wi(t) adalah headof - line (HOL) packet delay antrian user ke-i pada eNB subframe waktu ke-t. $\mathrm{Rj}(\mathrm{t})$ adalah data rate $\mathrm{UE}$ pada $s u b$ - channel ke-j.

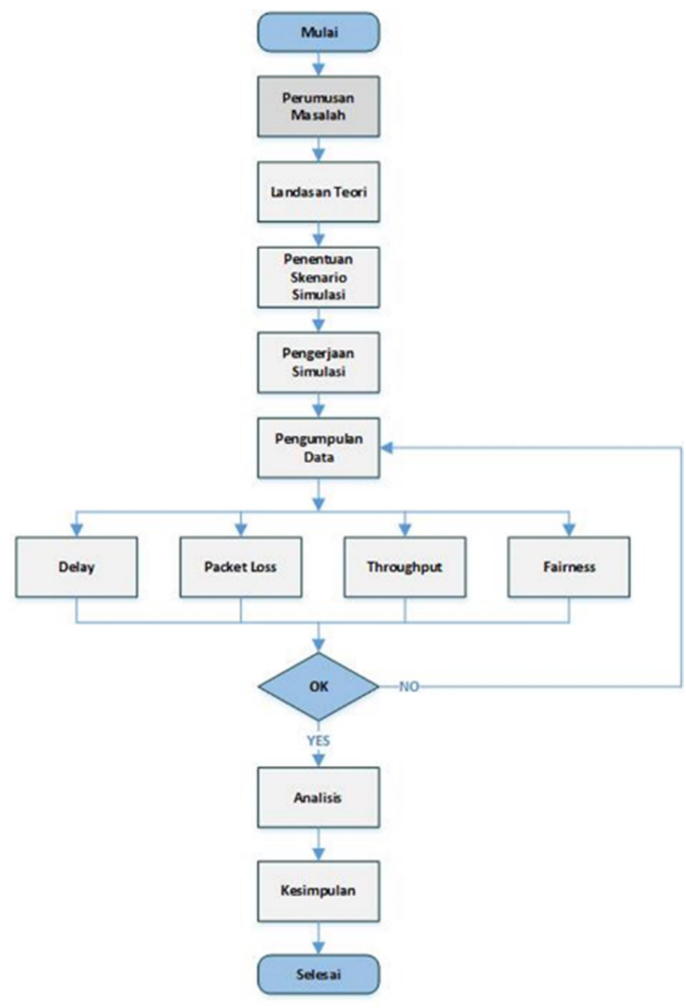

Gambar 2. Diagram Alir Penelitian
Pada bagian ini dijelaskan alir penelitian yang dilakukan, sebagaimana yang tertera pada Gambar 2 . Pada awalnya penulis mencari referensi yang terkait lalu menemukan beberapa permasalahan, kemudian mempelajari teori - teori yang mendukung penelitian ini diantaranya pengertian LTE, arsitektur LTE, QoS, penjadwalan, dan algoritma penjadwalan Proportional Fairness dan Log Rule. Setelah mempelajari teori tersebut dilakukan simulasi dengan skenario multicell dan meliputi sistem yang digunakan beserta parameter - parameternya, jumlah user, jumlah sel, dan kecepatan pergerakan user. Setelah dilakukan proses ini, maka akan didapat evaluasi dari parameter yang telah ditentukan yaitu berupa QoS nilai dari delay, packet loss, throughput, dan fairness, dan dari kedua algoritma tersebut. Apabila ada data error atau kejanggalan pada data, akan dilakukan pengulangan pengumpulan data. Selanjutnya akan ditinjau dan dianalisis kualitas hasil QoS dengan membandingkan dengan standard QoS ITU-T. Setelahnya akan didapatkan kesimpulan dari hasil analisis tersebut.

\section{Desain Simulasi Jaringan}

Model simulasi dari pengerjaan penelitian ini adalah pemodelan jaringan LTE yang terdiri dari 7 sel dimana terdapat 1 buah eNodeB pada masing masing sel dan beberapa UE yang dilayaninya dengan konfigurasi layanan sesuai dengan skenario simulasi. ENodeB terhubung dengan EPC sebagai core layanan yang diwakili oleh MME/GW dimana ini terhubung dengan beberapa server layanan [7]. Ilustrasi dapat dilihat pada Gambar 3.

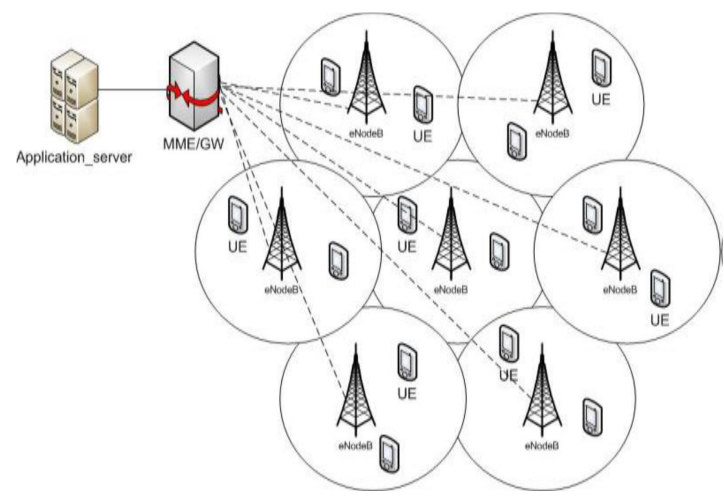

Gambar 3. Pemodelan Topologi Jaringan [7]

Simulasi dilakukan dengan model user yang bergerak dengan kecepatan tertentu, dan dapat mengalami handover. Tipe mobilitas user adalah random direction, dimana UE akan memilih arah pergerakan secara random yang bersifat konstan terhadap waktu, dan bergerak mendekati boundary area atau batas sel simulasi. Ketika UE sudah mencapai batas sel simulasi, UE akan memilih arah pergerakan baru [7]. Tipe mobilitas random direction ini di ilustrasikan seperti pada Gambar 4. 

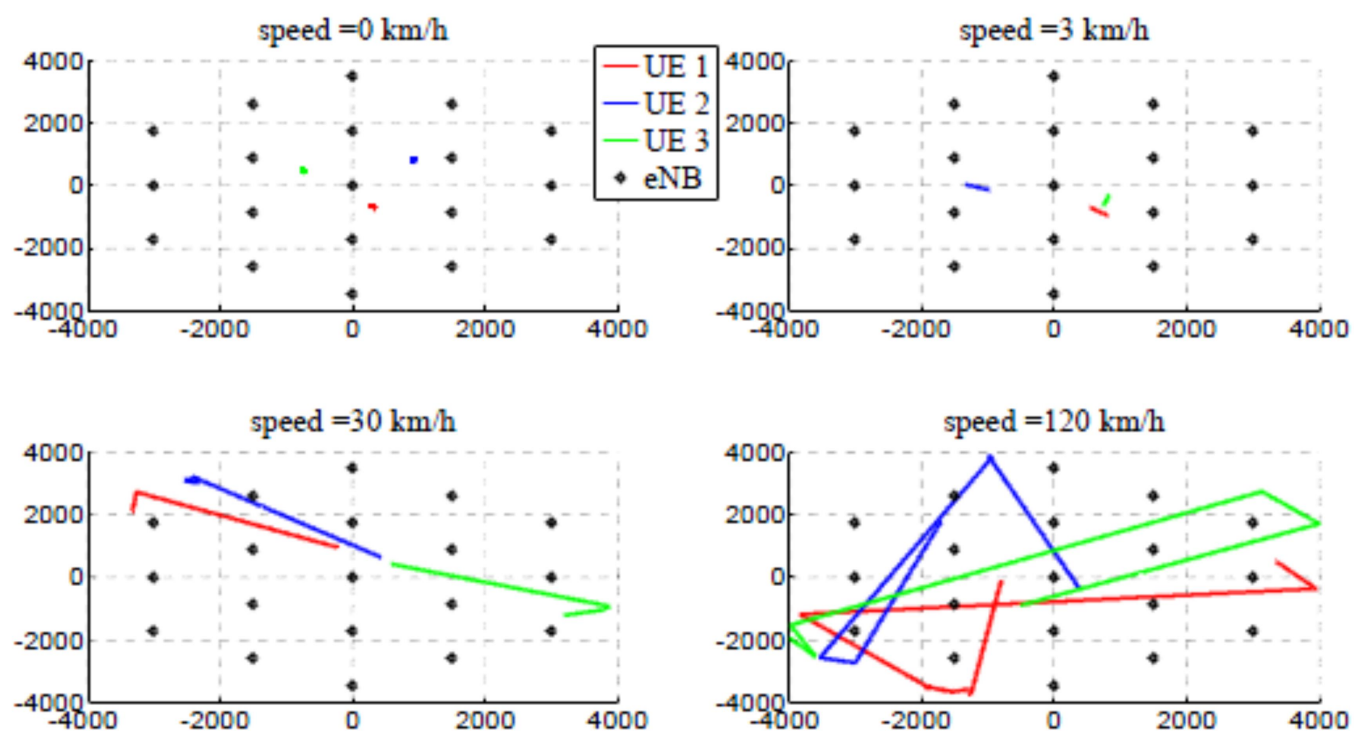

Gambar 4. Tipe Mobile Node [7]

Pada Tabel 2 berikut merupakan konfigurasi yang digunakan pada simulasi, mencakup parameter sistem secara umum, parameter aplikasi yang digunakan oleh user. Parameter sistem secara umum mengikuti konfigurasi default dari simulator. Nilai, jenis dan tipe dari parameter yang ada disesuaikan dengan standar LTE pada Release-8 [12]. Parameter sistem dapat dilihat di Tabel 2.

\begin{tabular}{|c|c|c|c|}
\hline \multicolumn{4}{|c|}{ System Parameter } \\
\hline Simulation Time & $100 \mathrm{~s}$ & Flows Duration & $100 \mathrm{~s}$ \\
\hline $\begin{array}{l}\text { Type of Frame } \\
\text { Structure }\end{array}$ & FDD & $\begin{array}{c}\text { System } \\
\text { Bandwidth }\end{array}$ & $10 \mathrm{MHz}$ \\
\hline $\begin{array}{c}\text { Number of } \\
\text { Resource Blocks }\end{array}$ & 50 & $\begin{array}{l}\text { Sub Carrier per } \\
\text { Resource Block }\end{array}$ & 12 \\
\hline $\begin{array}{l}\text { Max Delay } \\
\text { (Simulating) }\end{array}$ & $0.04 \mathrm{~s}$ & $\begin{array}{l}\text { Sub carrier } \\
\text { spacing }\end{array}$ & $15 \mathrm{kHZ}$ \\
\hline $\begin{array}{c}\text { Scheduling Time } \\
\text { (TTI) }\end{array}$ & $1 \mathrm{~ms}$ & $\begin{array}{l}\text { Sub Channel } \\
\text { Bandwidth }\end{array}$ & $180 \mathrm{kHz}$ \\
\hline Cell Number & 7 & Cell Radius & $1 \mathrm{~km}$ \\
\hline Antenna & $\begin{array}{l}\text { MIMO } \\
2 \times 2\end{array}$ & Handover & Yes \\
\hline Mobility Type & $\begin{array}{l}\text { Random } \\
\text { Direction }\end{array}$ & $\begin{array}{l}\text { Type of } \\
\text { Scheduler }\end{array}$ & $\begin{array}{l}\text { Proporti } \\
\text { onal and } \\
\text { Log Rule }\end{array}$ \\
\hline
\end{tabular}

Layanan dibangkitkan oleh beberapa trafik generator yakni trace based VoIP, Video dan Best Effort. Layanan VoIP dibangkitkan melalui voice flow G.729. Voice flow ini dimodelkan oleh ON/OFF Markov Chain dimana periode ON didistribusikan secara eksponensial dengan mean 3 detik dan periode OFF oleh eksponensial truncated dengan upper limit
6.9 detik dan nilai average 3 detik. Selama periode ON, source mengirimkan 20 byte paket setiap $20 \mathrm{~ms}$. Sedangkan pada periode OFF paket yang dikirimkan adalah 0 byte akibat pengaktifan Voice Activity Detector. Untuk layanan Video trafik berupa layanan traced-based, dimana pengiriman paket berdasarkan file Video trace realistis yang tersedia pada simulator. Untuk layanan Best Effort, trafik dimodelkan oleh infinite buffer yang akan selalu memiliki paket untuk dikirimkan [7]. Berikut ini adalah konfigurasi tipe layanan tertera pada Tabel 3 .

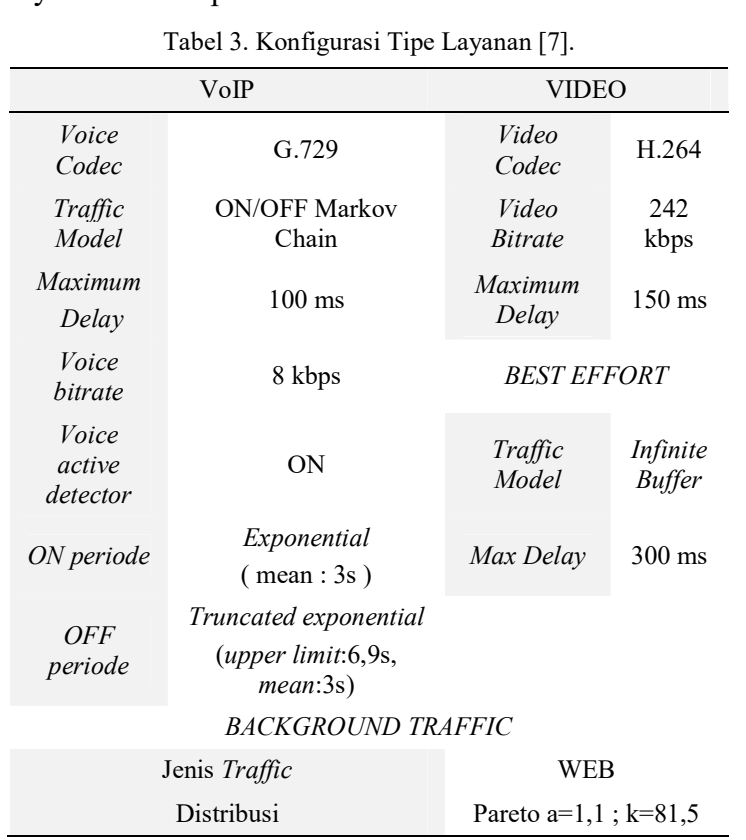




\section{E. Skenario Penelitian}

Simulasi skenario yang dibahas di penelitian ini dapat dikelompokkan menjadi 2 kelompok yaitu skenario perubahan jumlah user dan skenario perubahan kecepatan user dalam waktu 100 detik.

\section{F. Skenario 1, Perubahan Jumlah User}

Skenario ini diuji dengan melakukan simulasi penambahan jumlah user secara berkala mulai dari 25 , 50, 75, dan 100 user. Jumlah user ini digunakan berdasarkan penelitian - penelitian yang dilakukan sebelumnya, dimana fluktuasi QoS terjadi sampai dengan jumlah 100 user, dimana lebih dari itu grafik yang dihasilkan oleh parameter keluaran cenderung stabil. Pada simulasi, masing - masing user bergerak dengan kecepatan konstan menggunakan tipe mobilitas random direction. Sejumlah user yang disimulasikan tersebar pada 7 buah sel dengan radius $1 \mathrm{~km}$ pada masing - masing selnya, dan menggunakan distribusi uniform. Tiap user akan membangkitkan trafik layanan VoIP, Video dan BE dengan perbandingan 1:1:1 flow dalam waktu bersamaan selama 100 detik. Informasi yang diambil dari masingmasing simulasi terdiri dari delay, throughput, packet loss ratio, dan fairness index [7].

\section{G. Skenario 2, Perubahan Kecepatan User}

Skenario ini diuji pada 50 user yang bergerak dengan kecepatan 3, 30, dan $120 \mathrm{~km} / \mathrm{jam}$ sesuai dengan standar pedestrian dan vehicle yang dikeluarkan oleh ITU-T [8]. Pada skenario ini, simulasi dilakukan selama 100 detik, dimana user bergerak menggunakan tipe mobilitas random direction, dimana handover user tidak didefinisikan sehingga jumlah handover yang terjadi pada simulasi disesuaikan dengan pergerakan user sesuai dengan kecepatannya masing-masing. Layanan yang diakses user, perbandingan jumlah flow layanan tiap user, dan informasi output sama seperti pada skenario 1 [7].

\section{HASIL DAN PEMBAHASAN}

Pada bagian ini disajikan analisis hasil simulasi scenario perubahan jumlah user, dimana simulasi dilakukan pada 25, 50, 75, dan 100 user yang bergerak dengan kecepatan $3 \mathrm{~km} / \mathrm{jam}$ dan tersebar di $7 \mathrm{sel}$ dengan radius sel sebesar $1 \mathrm{~km}$.

\section{A. Skenario 1, Perubahan Jumlah User}

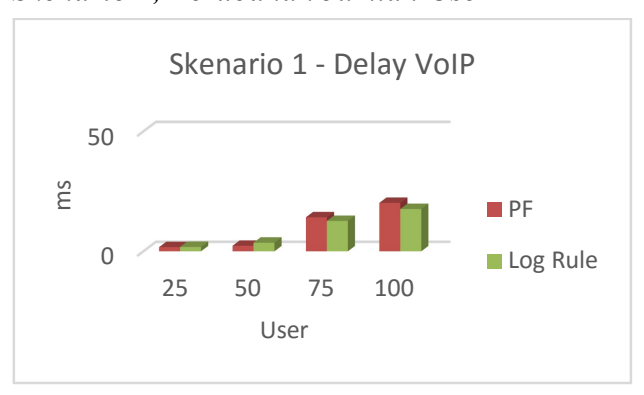

Gambar 5. Grafik Delay VoIP Pada Skenario 1
Pada Gambar 5, performansi algoritma Log Rule ketika jumlah user kecil, delay yang dihasilkan juga kecil hal ini dikarenakan karateristik algoritma Log Rule adalah meminimalisir delay jaringan dan delay HOL. Pada algoritma Proportional Fairness cukup bersaing saat jumlah user relatif sedikit dikarenakan algoritma Proportional Fairness memperhatikan dan sensitif terhadap nilai preference metrik. Kedua Algoritma masih memenuhi standar untuk layanan real-time VoIP sesuai dengan standarisasi ITU-T, yaitu dibawah $100 \mathrm{~ms}$.

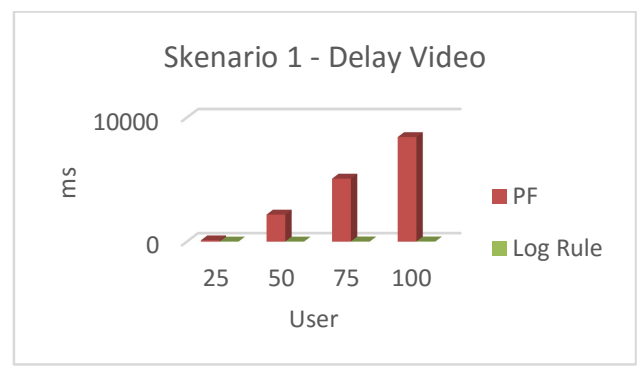

Gambar 6. Grafik Delay Video Pada Skenario 1

Dari Gambar 6, terlihat performansi algoritma $\log$ Rule jauh lebih baik dari algortima Proportional Fairness karena pada perhitungannya terdapat parameter delay dan delay HOL. Pada layanan Video di algoritma Proportional Fairness terdapat anomali pada hasil simulasi karena dalam perhitungan algoritma Proportional Fairness tidak ada parameter delay dan nilai preference metric. Pada layanan Video lebih besar dari layanan VoIP mengakibatkan kurangnya prioritas yang menyebabkan tingginya nilai delay pada layanan Video. Sehingga dalam layanan Video tidak dianjurkan menggunakan algortima Proportional Fairness karena nilai delay nya mencapai 9 detik sehingga tidak memenuhi standar ITU-T yaitu $150 \mathrm{~ms}$.

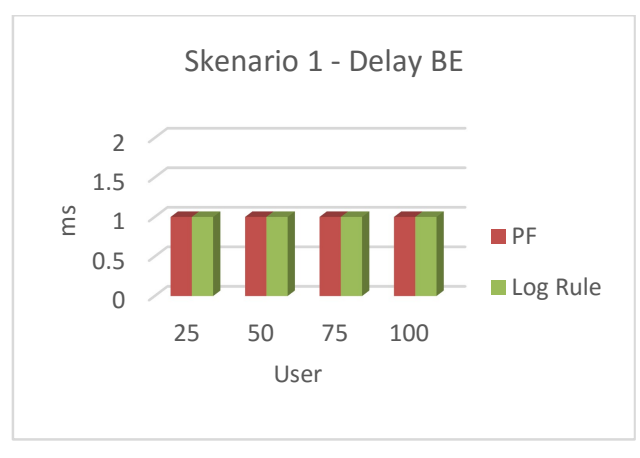

Gambar 7. Grafik Delay BE pada Skenario 1

Pada Gambar 7, seperti yang dijelaskan sebelumnya, layanan $B E$ dimodelkan oleh infinite buffer sehingga delay yang dihasilkan kedua algoritma, Proportional Fairness dan Log Rule akan selalu konstan yaitu 0.001 detik. Hal ini menunjukan bahwa layanan $B E$ selalu memiliki paket untuk 
dikirimkan. Untuk layanan non real-time kedua algoritma ini masih memenuhi batas standar ITU-T yaitu dibawah $300 \mathrm{~ms}$.

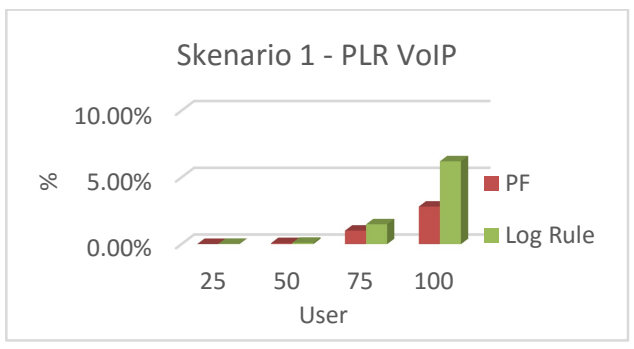

Gambar 8. Grafik PLR VoIP Pada Skenario 1

Terlihat dari Gambar 8, pada kedua algoritma menunjukan semakin besar jumlah user maka semakin besar pula packet loss yang dihasilkan. Hal ini disebabkan delay yang meningkat. Dapat dilihat pada algoritma Log Rule nilai PLR meningkat tajam saat jumlah user dan beban jaringan meningkat. Untuk algoritma Proportional Fairness lebih baik karena dengan karateristik algoritma ini yang sensitif dengan preference metrik menyebabkan lebih unggul dalam layanan VoIP. Algortima Proportional Fairness memiliki batas PLR $2.81 \%$ tergolong sangat baik $(0 \%$ - 3\%) dan algoritma Log Rule memiliki batas PLR $6.2 \%$ tergolong baik $(3 \%-15 \%)$.

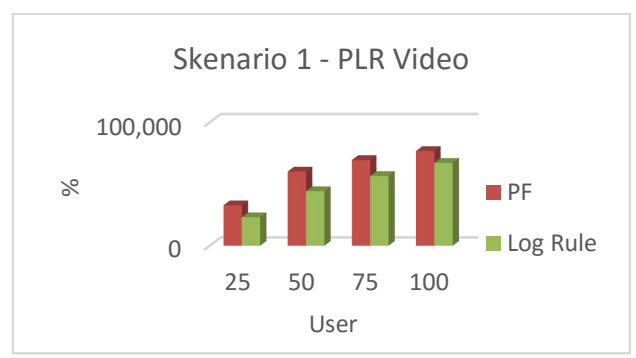

Gambar 9. Grafik PLR Video pada Skenario 1

Pada Gambar 9, algoritma Proportional Fairness yang pada perhitungannya tidak melibatkan parameter delay dan preference metric pada Video lebih besar dari VoIP menyebabkan tingginya nilai delay yang dihasilkan sehingga terjadi packet drop. Hal ini yang menyebabkan tingginya PLR pada layanan Video. Algortima Proportional Fairness memiliki batas PLR $76.7 \%$ tergolong sangat buruk $(>25 \%)$ dan algoritma Log Rule memiliki batas PLR 67.1\% tergolong sangat buruk (>25\%). Dapat disimpulkan untuk layanan PLR Video kedua algoritma sangat tidak dianjurkan untuk diterapkan.

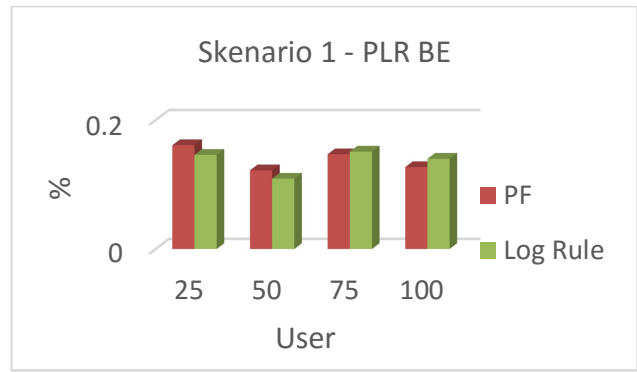

Gambar 10. Grafik PLR BE pada Skenario 1

Pada jumlah user sedikit, kedua algoritma tersebut sama-sama mengalami penurunan yang disebabkan karena rendahnya beban trafik yang dilayani oleh kedua algoritma. Akan tetapi, ketika user bertambah algoritma Log Rule memberikan peningkatan yang jauh lebih baik dibandingkan Proportional Fairness.Variasi bentuk grafik kedua algoritma seperti pada Gambar 10, menunjukkan bahwa kedua algoritma ini kurang baik digunakan pada layanan non real-time seperti Best Effort. Namun kedua algortima tersebut masih dapat dikatakan sangat baik (PLR $<25 \%$ ).

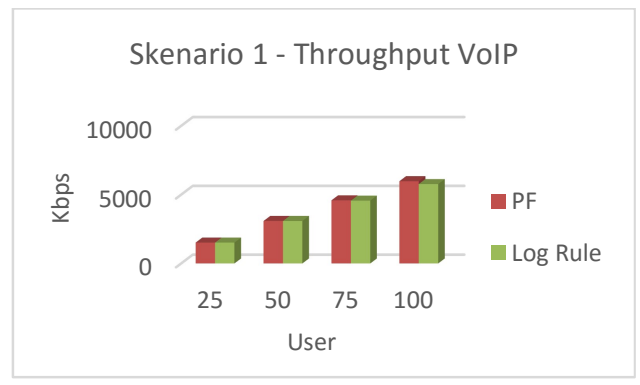

Gambar 11. Grafik Throughput VoIP pada Skenario 1

Pada Gambar 11, meningkatnya throughput di kedua algoritma dikarenakan kedua algortima memiliki karateristik yaitu memaksimalkan throughput jaringan terutama algortitma Proportional Fairness. Meskipun keduanya memiliki karateristik memaksimalkan throughput namun algoritma Proportional Fairness lebih unggul di layanan VoIP. Besarnya throughput pada algoritma Proportional Fairness juga dipengaruhi oleh PLR pada layanan VoIP.

Pada Gambar 12, algoritma Proportional Fairness dan Log Rule memiliki karateristik memaksimalkan throughput. Meskipun keduanya memiliki karateristik memaksimalkan throughput namun algoritma Log Rule lebih unggul di layanan Video dikarenakan layanan Video memiliki nilai preference metrik yang besar. Besarnya throughput pada algoritma Log Rule juga dipengaruhi oleh PLR pada layanan Video. 


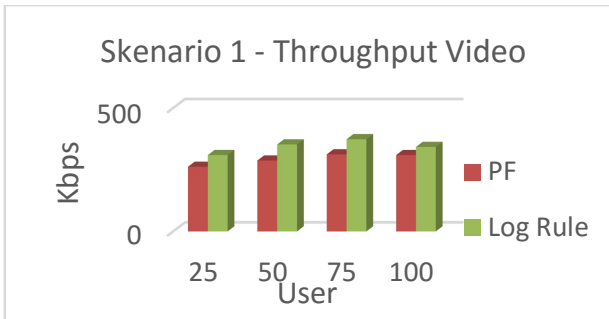

Gambar 12. Grafik Throughput Video pada Skenario 1

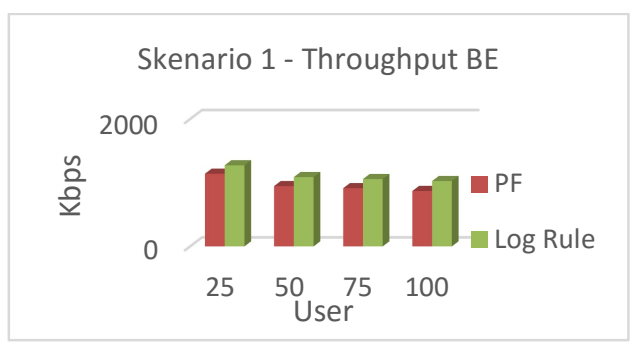

Gambar 13. Grafik Throughput BE pada Skenario 1

Dari Gambar 13, terlihat bahwa pada kedua algoritma seiring bertambahnya jumlah user, throughput yang dihasilkan pun akan semakin menurun. Hal ini disebabkan layanan $B E$ dibangkitkan bersamaan dengan layanan real-time dimana performansi kedua algoritma Proportional Fairness dan Log Rule yang sama-sama memprioritaskan peningkatan throughput pada layanan real-time.

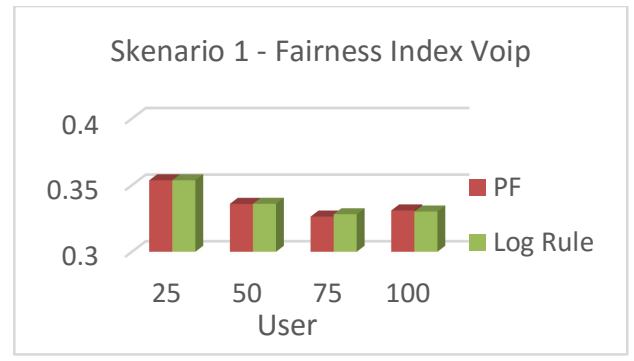

Gambar 14. Grafik FI VoIP pada Skenario 1

Pada Gambar 14, secara umum dari ketiga jenis trafik yang dibangkitkan, yaitu VoIP, Video dan Best Effort terus mengalami penurunan dalam fairness index. Hal ini disebabkan pengaruh dari kepadatan trafik dan jumlah paket yang diterima pengguna dalam waktu tertentu. Dari grafik dapat dilihat bahwa semakin besar jumlah user maka semakin menurun jumlah kualitas Fairness index-nya. Hal ini disebabkan karena kepadatan trafik pada layanan VoIP. Kedua algoritma tersebut masih jauh dari nilai ambang batas Fairness index yang di tetapkan ITU-T, yaitu 1.

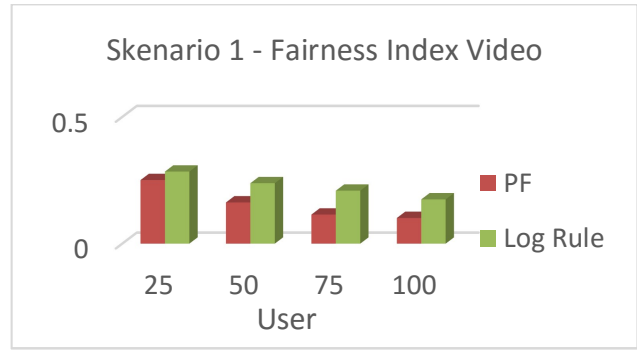

Gambar 15. Grafik FI Video pada Skenario 1

Pada Gambar 15, menunjukan hasil dari perbandingan nilai fairness index untuk algoritma Proportional Fairness dan Log Rule. Dari grafik dapat disimpulkan bahwa semakin besar jumlah user maka semakin menurun jumlah kualitas Fairness index-nya. Hal ini disebabkan karena kepadatan trafik pada layanan Video. Kedua algoritma tersebut masih jauh dari nilai ambang batas Fairness index yang ditetapkan ITU-T, yaitu 1.

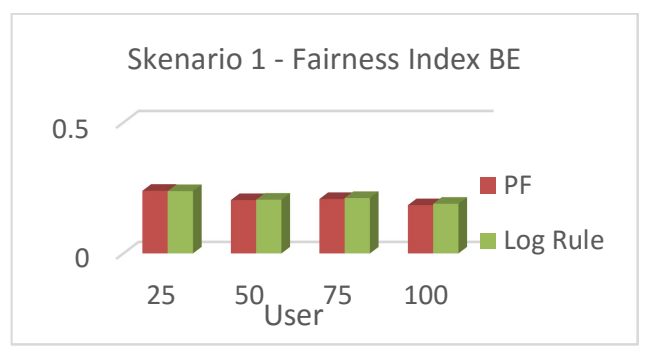

Gambar 16. Grafik FI BE pada Skenario 1

Pada Gambar 16, menunjukan hasil dari perbandingan nilai fairness index untuk algoritma Proportional Fairness dan Log Rule. Dari grafik dapat disimpulkan bahwa semakin besar jumlah user maka semakin menurun jumlah kualitas Fairness index-nya. Hal ini disebabkan karena kepadatan trafik pada layanan Best Effort. Kedua algoritma tersebut masih jauh dari nilai ambang batas Fairness index yang di tetapkan ITU-T, yaitu 1.

\section{B. Analisis Skenario Perubahan Kecepatan User}

Pada bagian ini disajikan analisis hasil simulasi scenario perubahan kecepatan user menggunakan model Jackes Channel sesuai standar kecepatan pedestrian dan vehicle yang di standarkan oleh ITU-T [8], dimana simulasi dilakukan pada 3, 30, dan 120 $\mathrm{km} / \mathrm{jam}$ dengan $u$ ser sebesar 50 dan tersebar di 7 sel dengan radius masing-masing sel sebesar $1 \mathrm{~km}$.

Terlihat pada Gambar 17, performansi algoritma Proportional Fairness lebih baik dikarenakan pada layanan VoIP memiliki nilai preference metric kecil sehingga algoritma Proportional Fairness mempunyai nilai delay yang lebih rendah. Pada algoritma Log Rule juga dapat mempertahankan performansinya 
terhadap delay dikarenakan pada perhitungannya terdapat parameter delay dan delay HOL.

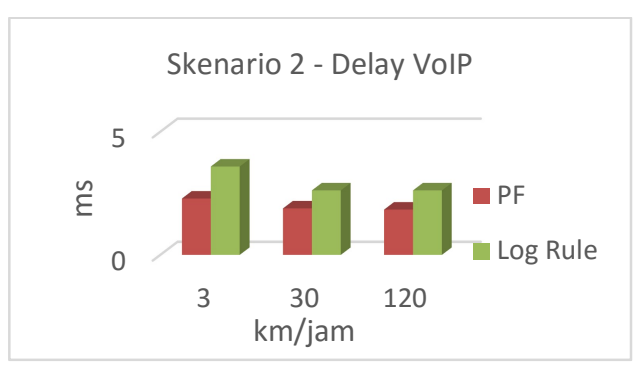

Gambar 17. Grafik Delay VoIP pada Skenario 2

Dari keseluruhan hasil nilai delay kedua algoritma masih memenuhi standar delay untuk layanan realtime VoIP yang di standarisasi ITU-T yaitu dibawah $100 \mathrm{~ms}$.

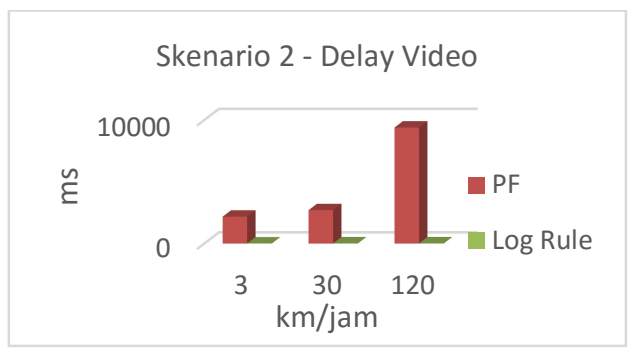

Gambar 18. Grafik Delay Video pada Skenario 2

Terlihat pada Gambar 18, performansi Log Rule untuk real-time Video lebih baik dari algoritma Proportional Fairness, ini disebabkan pada perhitungan algoritma Log Rule terdapat parameter delay dan parameter delay HOL.

Pada algoritma Proportional Fairness terlihat jelas peningkatan yang cukup tajam dikarenakan karateristik algoritma ini tidak memperhatikan delay dan pada layanan Video memiliki nilai preference metrik yang besar. Algoritma Proportional Fairness tidak memenuhi batas delay yang di tetapkan ITU-T karena melebihi $150 \mathrm{~ms}$.

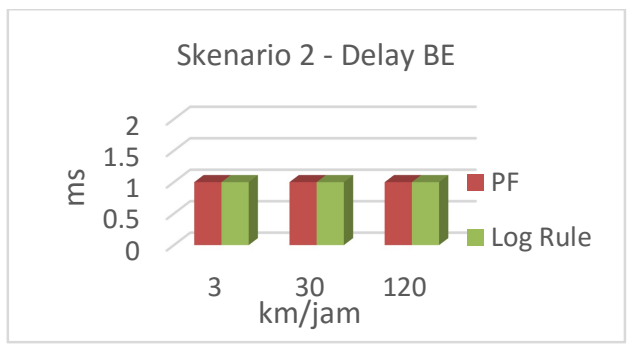

Gambar 19. Grafik Delay BE pada Skenario 2

Pada Gambar 19, seperti yang dijelaskan sebelumnya, layanan $B E$ dimodelkan oleh infinite buffer sehingga delay yang dihasilkan kedua algoritma
Proportional Fairness dan Log Rule akan selalu konstan yaitu 0.001 detik. Hal ini menunjukan bahwa layanan $B E$ selalu memiliki paket untuk dikirimkan. Untuk layanan non real-time kedua algoritma ini masih memenuhi batas standar ITU-T yaitu dibawah $300 \mathrm{~ms}$.

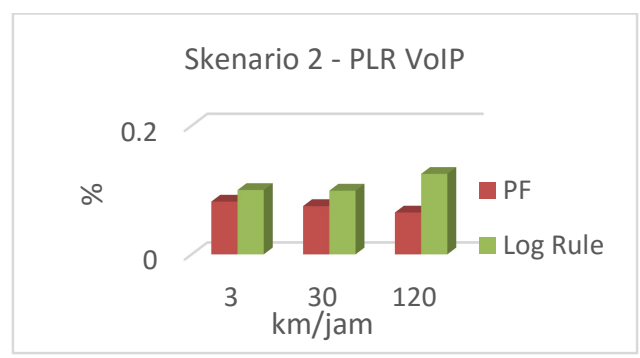

Gambar 20. Grafik PLR VoIP pada Skenario 2

Terlihat pada Gambar 20, performansi Log Rule mengalami lonjakan PLR yang cukup besar ketika user mempercepat pergerakannya. Hal ini disebabkan tingginya delay yang menyebabkan adanya packet drop.

Pada algoritma Proportional Fairness terlihat lebih baik dikarenakan pada layanan VoIP memiliki nilai peference metrik yang kecil sehingga seiring bertambahnya kecepatan, algoritma ini dapat mengatasi masalah PLR lebih baik daripada algoritma Log Rule. Namun dari kedua algoritma tersebut samasama memenuhi batas delay yang distandarisasi ITUT karena PLR $<25 \%$.

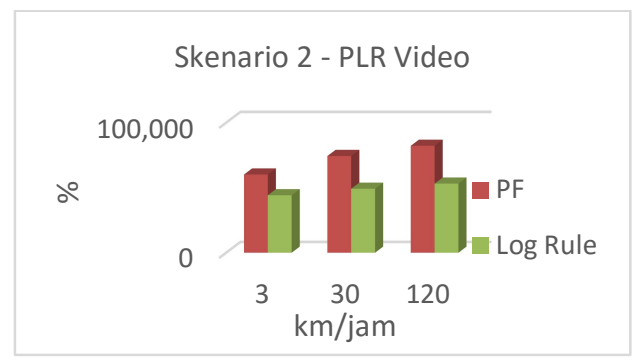

Gambar 21. Grafik PLR Video pada Skenario 2

Terlihat pada Gambar 21, performansi algoritma Proportional Fairness mengalami lonjakan yang tinggi daripada algoritma Log Rule. Hal ini disebabkan pada algoritma ini dalam perhitungannya tidak memasukan parameter delay dan pada layanan Video memiliki nilai preference metric yang lebih besar dari layanan VoIP yang berpengaruh pada sistem prioritas sehingga menyebabkan tingginya delay. Tingginya delay menyebabkan terjadinya packet drop yang mengakibatkan nilai PLR tinggi. Kedua algoritma tersebut sama-sama tidak memenuhi batas PLR yang di standarisasi ITU-T karena PLR > $25 \%$. 


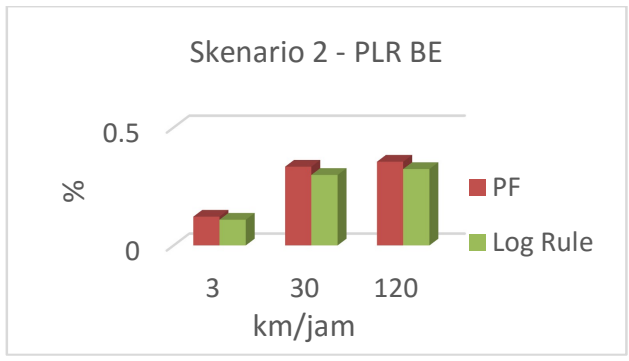

Gambar 22. Grafik PLR BE pada Skenario 2

Pada Gambar 22, performansi kedua algoritma meningkat seiring user mulai bergerak. Hal ini dikarenakan kondisi kanal yang memburuk dengan penambahan kecepatan user. Kedua algoritma masih memenuhi standar ITU-T karena nilai PLR $<25 \%$.

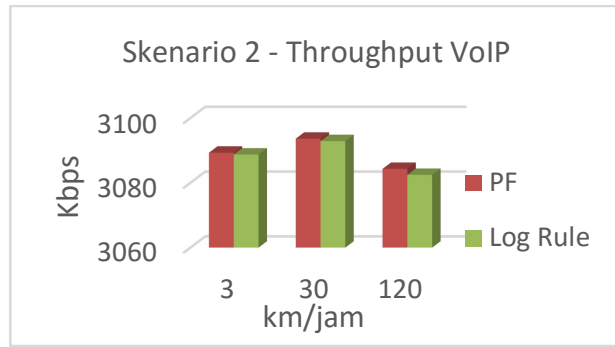

Gambar 23. Grafik Throughput VoIP pada Skenario 2

Dari Gambar 23, terlihat bahwa kedua algoritma sempat mengalami kenaikan ketika kecepatan 30 $\mathrm{km} / \mathrm{jam}$. Namun seiring bertambahnya kecepatan $u$ ser, pada kecepatan $120 \mathrm{~km} / \mathrm{jam}$, throughput yang dihasilkan semakin berkurang. Hal ini disebabkan performansi kedua algoritma pada saat kecepatan 30 $\mathrm{km} / \mathrm{jam}$ memiliki nilai PLR yang rendah, sehingga dampak terhadap throughput pun tinggi. Kurangnya performansi algoritma Proportional Fairness dan Log Rule ketika kecepatan $120 \mathrm{~km} / \mathrm{jam}$ dipengaruhi PLR sehingga berdampak pada throughput yang menurun. Namun dari kedua algoritma tersebut, algoritma Proportional Fairness masih memberikan keunggulan dalam hal throughput dikarenakan algoritma Proportional Fairness cenderung lebih baik di layanan VoIP.

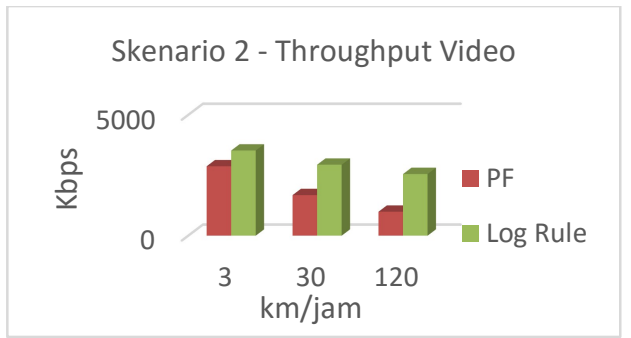

Gambar 24. Grafik Throughput Video pada Skenario 2
Dari Gambar 24, terlihat pada kedua algoritma, seiring bertambahnya kecepatan user, throughput yang dihasilkan semakin berkurang. Hal ini disebabkan pada performansi algoritma Proportional Fairness dan Log Rule ketika kecepatan user bertambah mulai dari 3, 30, dan $120 \mathrm{~km} / \mathrm{jam}$, nilai PLR untuk layanan real-time Video yang tinggi, sehingga berdampak pada throughput yang rendah.

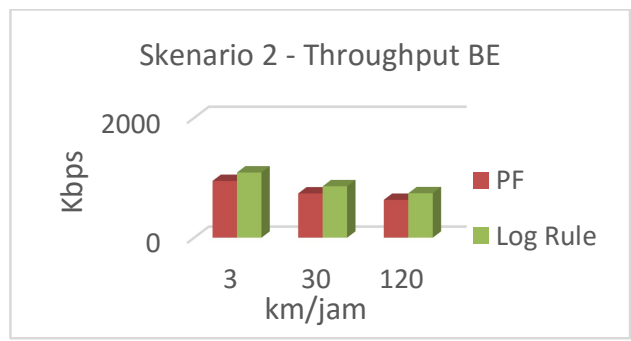

Gambar 25. Grafik Throughput BE pada Skenario 2

Dari Gambar 25, terlihat bahwa seiring bertambahnya kecepatan user pada kedua algoritma, throughput yang dihasilkan pun semakin berkurang. Hal ini disebabkan layanan $B E$ dibangkitkan bersamaan dengan layanan real-time, dimana performansi kedua algoritma sama-sama memprioritaskan meningkatkan throughput pada layanan real-time, sehingga menyebabkan penurunan pada layanan non real-time. Performansi algoritma Log Rule masih dapat mempertahankan throughput disebabkan kondisi kanal yang baik.

Pada Gambar 26, kenaikan Fairness Index pada algoritma Log Rule, bagi user dengan kecepatan 30 $\mathrm{km} / \mathrm{jam}$ disebabkan karena paket yang berhasil dikirim lebih tinggi, kepadatan trafik VoIP rendah, serta kondisi kanal yang baik. Sedangkan penurunan yang tidak terlalu signifikan ketika kecepatan $120 \mathrm{~km} / \mathrm{jam}$ disebabkan mobilitas random direction yang dialami user yang mengakibatkan efek Doppler dan pathloss. Performansi kedua algoritma ini masih di bawah batas standar ITU-T yang ditentukan untuk FI yaitu 1 .

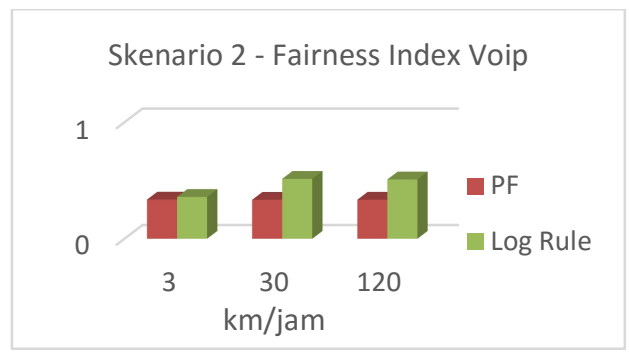

Gambar 26. Grafik FI VoIP pada Skenario 2 


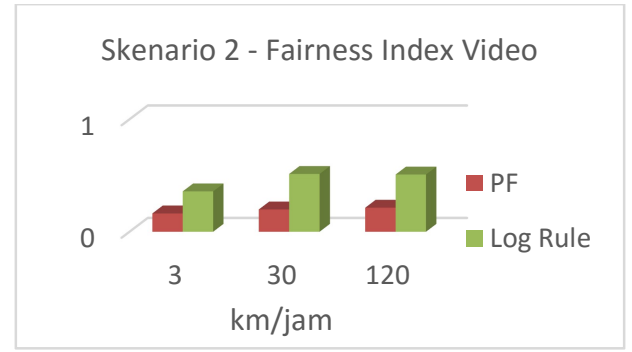

Gambar 27. Grafik FI Video pada Skenario 2

Dari Gambar 27, terlihat bahwa seiring bertambahnya kecepatan user pada kedua algoritma, FI yang dihasilkan semakin meningkat. Penyebabnya sama seperti halnya pada layanan VoIP yang telah dijelaskan sebelumnya. Performansi kedua algoritma tersebut untuk layanan Video masih dibawah standar ITU-T yaitu 1 .

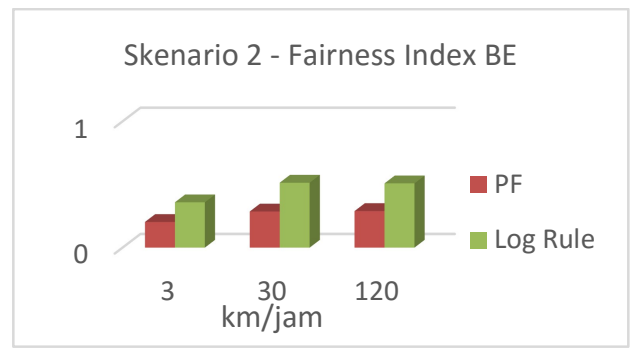

Gambar 28. Grafik FI $B E$ pada Skenario 2

Dari Gambar 28, terlihat bahwa seiring bertambahnya kecepatan user pada kedua algoritma tersebut, nilai FI yang dihasilkan semakin berkurang. Penyebabnya sama halnya seperti pada layanan VoIP dan Video yang telah dijelaskan sebelumnya. Performansi kedua algoritma tersebut untuk layanan BE masih di bawah standar ITU-T yaitu 1.

\section{PENUTUP}

\section{A. Kesimpulan}

Dari hasil simulasi dan analisis yang telah dilakukan pada perangkat lunak berbasis open source LTE-SIM dapat diambil beberapa kesimpulan, yaitu:

1. Algoritma Proportional Fairness memperhitungkan sumber daya ratio dan preference metrik, terbukti pada saat layanan VoIP algoritma ini lebih baik karena pada layanan VoIP memiliki preference metrik yang lebih baik dari pada Video dan $B E$.

2. Algoritma Log Rule bertujuan untuk meminimalkan delay, terbukti meski jumlah user bertambah ataupun kecepatan user berubah, algoritma Log Rule mampu meminimalkan delay dari kedua layanan real-time yaitu VoIP dan Video.

3. Pada skenario penambahan jumlah user dan penambahan kecepatan user untuk layanan real- time VoIP, penggunaan algoritma Proportional Fairness lebih cocok didasarkan atas nilai PLR yang rendah, throughput yang tinggi, dan tingkat keadilan yang cukup merata untuk setiap layanan.

4. Pada skenario penambahan jumlah user dan penambahan kecepatan user untuk layanan realtime Video penggunaan algoritma Log Rule lebih cocok didasarkan atas nilai PLR yang rendah, throughput yang tinggi, dan tingkat keadilan yang cukup merata untuk setiap layanan.

5. Untuk layanan non real-time seperti $B E$ pada jumlah user bertambah ataupun kecepatan user berubah penerapan kedua penjadwalan Proportional Fairness dan Log Rule kurang cocok. Karena kedua algoritma ini memprioritaskan layanan real-time yaitu VoIP dan Video.

B. Saran

Tugas Akhir ini sangat memungkinkan untuk dikembangkan khususnya untuk analisis penjadwalan. Adapun saran untuk pengembangan selanjutnya adalah:

1. Melakukan simulasi dan analisis penjadwalan Proportional Fairness dan Log Rule pada lingkungan yang berbeda.

2. Melakukan simulasi dan analisis perbandingan Log Rule dengan menggunakkan penjadwalan lain seperti MLWDF, EXP RULE, FLS pada multicell.

3. Melakukan pengujian dan simulasi dengan bitrate lebih tinggi pada layanan Video.

\section{DAFTAR PUSTAKA}

[1] Ali.S, Zeeshan.M.. A Utility Based Resource Allocation Scheme with Delay Scheduler for LTE Service-Class Support. IEEE Wireless Communication and Networking Conference: MAC and CrossLayer Design. 2012

[2] Dikamba, T. Downlink Scheduling In 3GPP Long Term Evolution, Delft University of Technology. 2011

[3] Elvyra, Sari. Analisis Performansi Penjadwalan Paket Pada Jaringan LTE (Long Term Evolution) Arah Downlink untuk Mendukung Layanan Triple Play. 2011

[4] Giuseppe, PiroLTE. LTE Simulator. Diambil dari: www.telematics.poliba.it/index.php/en/lte-sim. 2011

[5] Haryati, Vidya. Analisa QoS Long Term Evolution (LTE) Terhadap Pengaplikasian Interface X2 Saat Handover. 2012

[6] Hill B, Miriam B, Michael B. OFDMA System, Pilot Signal and Doppler Effect. 2009

[7] Karimah Amatullah, Sitti. Analisis Perbandingan Algoritma Penjadwalan PF dan MLWDF Pada Kasus Multicell Jaringan Long Term Evolution. 2012

[8] Piro.G, Alfredo.L, Boggia.G. Simulating. LTE Cellular System : an Open Source Framework II. IEEE TRANS. VEH. TECHNOL. 2010

[9] Setiawan, Alvin. Bagus. Analisis Performansi Algoritma Penjadwalan: Log Rule dan Exponential Rule pada Jaringan LTE. 2012 
ISSN : 2085-3688; e-ISSN : 2460-0997

Analisa Performansi Algoritma Penjadwalan Proportional Fairness Dan Log Rule Dengan Skenario Multicell Pada Sistem 3GPP LTE

[10] Sivasubramaniam, Anand. Analyzing the Short Term Fairness of IEEE 802.11 in Wireless Multihop Radio Networks. 2002

[11] Suryaman, B. Perbandingan Performansi Algoritma Penjadwalan Round Robin, Maximum C/I, dan Proportional Fair dengan Menggunakan HARQ pada Sistem 3GPP LTE.
[12] Overview of 3GPP Release 8 V0.3.3 (2014-09) Diambil dari: http://www.3gpp.org/ftp/Information/ WORK_PLAN/Description_Releases/Rel08_description_20140924.zip 